\title{
Multi-Risk Assessment and Management-A Comparative Study of the Current State of Affairs in Chile and Ecuador
}

\author{
Stefan Greiving 1,2,*®D, Leonie Schödl ${ }^{2}$, Karl-Heinz Gaudry ${ }^{3,4}$, Iris Katherine Quintana Miralles ${ }^{5}$, \\ Benjamín Prado Larraín ${ }^{6}$, Mark Fleischhauer ${ }^{1,2}$, Myriam Margoth Jácome Guerra ${ }^{7}$ and Jonathan Tobar ${ }^{3}$ \\ 1 Institut für Raumplanung (IRPUD), TU Dortmund University, 44227 Dortmund, Germany; \\ mark.fleischhauer@tu-dortmund.de \\ 2 Plan + Risk Consult, 44227 Dortmund, Germany; schoedl@plan-risk-consult.de \\ 3 Instituto de Investigación Geológico y Energético (IIGE), Quito 170518, Ecuador; \\ karl.gaudry@geoenergia.gob.ec or karl.gaudry@cimonline.de (K.-H.G.); \\ jonathan.tobar@geoenergia.gob.ec (J.T.) \\ 4 Centre for International Migration and Development (GIZ/CIM), 65760 Eschborn, Germany \\ 5 Independent Researcher, Lima 15000, Peru; iquintanamiralles@gmail.com \\ 6 Independent Researcher, Santiago 92101, Chile; benjamin.pradolarrain@gmail.com \\ 7 Institute for Housing and Urban Development Studies (IHS), Erasmus University Rotterdam, \\ 3062 PA Rotterdam, The Netherlands; myryamjc10@gmail.com \\ * Correspondence: stefan.greiving@tu-dortmund.de
}

check for updates

Citation: Greiving, S.; Schödl, L.; Gaudry, K.-H.; Quintana Miralles, I.K.; Prado Larraín, B.; Fleischhauer, M.; Jácome Guerra, M.M.; Tobar, J. Multi-Risk Assessment and Management-A Comparative Study of the Current State of Affairs in Chile and Ecuador. Sustainability 2021, 13, 1366. https://doi.org/10.3390/ su13031366

Academic Editor: Antonio Finizio

Received: 12 December 2020

Accepted: 25 January 2021

Published: 28 January 2021

Publisher's Note: MDPI stays neutral with regard to jurisdictional claims in published maps and institutional affiliations.

Copyright: (c) 2021 by the authors. Licensee MDPI, Basel, Switzerland. This article is an open access article distributed under the terms and conditions of the Creative Commons Attribution (CC BY) license (https:/ / creativecommons.org/licenses/by/ $4.0 /)$.

\begin{abstract}
In Chile and Ecuador, multiple hazards and dynamic processes in vulnerability pose a high risk. Spatial planning and emergency management can contribute to disaster risk management but they follow different goals. However, global goals, such as from UN-ISDR (United Nations International Strategy for Disaster Risk Reduction) and UN SDGs (Sustainable Development Goals) can potentially support cities and regions in defining concerted action. This paper aims at measuring the performance of Chile and Ecuador in regard to the aforementioned policy goals. Although both countries show considerable progresses in the implementation of the UN strategies, it is doubtful that the existing global monitoring approach is appropriately designed for measuring the real situation on the ground. Our paper is based on a desktop research combined with stakeholder workshops and expert interviews. Overall, both countries made considerable progress in regard to disaster preparedness and monitoring. However, multi-risks are rarely considered and there is still increasing vulnerability due to the expansion of informal settlements. The risk management is characterized by an imbalanced distribution of financial resources and institutional capacities between the metropolitan regions and smaller municipalities, and by low public participation and hardly community-based approaches. The paper underlines the importance for more qualitative, in-depth studies on the root causes of disaster risk which could complement the global monitoring which is very much focused on quantitative data and shows inconsistency between input and output indicators.
\end{abstract}

Keywords: disaster risk; vulnerability; monitoring; risk assessment; disaster management; UNISDR; SDGs

\section{Introduction}

Worldwide, disaster risk and climate change are emerging topics, which are, in the Global South, deeply intertwined with rapid urbanization processes and population growth, which applies also to the Latin American Countries of Chile and Ecuador that are the focus of this paper. Disaster risks are seriously determined by the vulnerability of an exposed place.

Coping with these threats is one of the key objectives of the global policy agenda, manifested by the seven global targets of the Sendai Framework for Disaster Risk Reduction [1] and the 17 Sustainable Development Goals (SDGs), adopted by all UN Member States in 
2015, as part of the 2030 Agenda for Sustainable Development which set out a 15-year plan to achieve these goals [2].

A set of 38 indicators [3] was identified by UN-ISDR (United Nations International Strategy for Disaster Risk Reduction) to measure the global progress in the implementation of the Sendai Framework for Disaster Risk Reduction. The indicators measure progress in achieving the global targets of the Sendai Framework, and determine global trends in the reduction of risk and losses [3].

In principle, there are a couple of explicit relationships between several targets of the SDGs and the Sendai Framework, namely SDGs 1, 11 and 13: eradication of poverty, resilient and sustainable cities, and action to climate change, as shown by Figure 1. For these communalities, a joint monitoring scheme has been adopted by the UN.

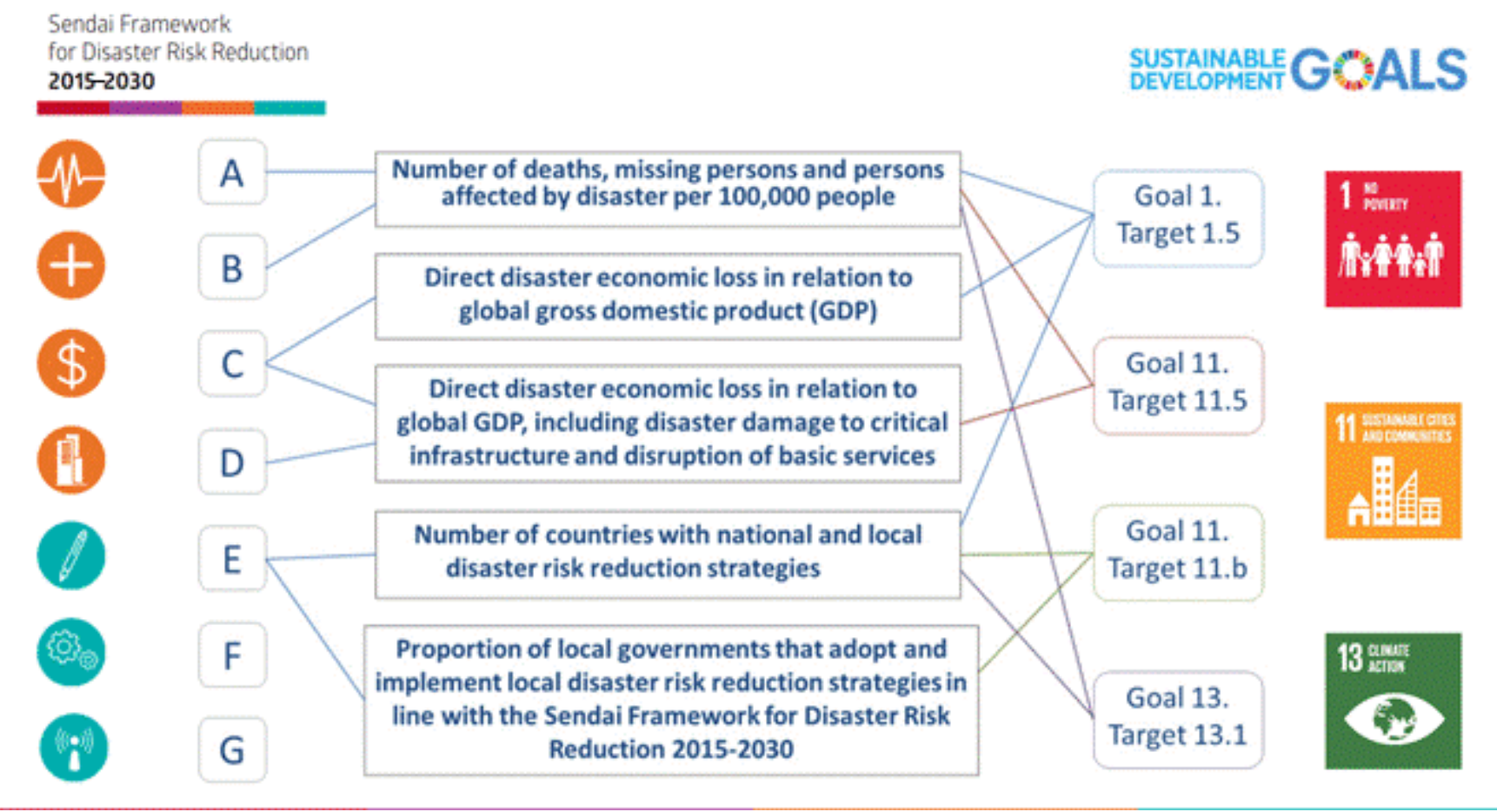

Figure 1. Sendai Framework and the 2030 Agenda [4].

For this purpose, the UN-ISDR publishes every year a so-called "Global Assessment Report" on global and national level key achievements in regard to these 38 indicators [5]. Data reported by Member States against the global plan to reduce disaster risk and losses is publicly available [6]. However, only few UN Member States have fulfilled their full reporting requirements and 79 started to enter global target's data. Here, Chile's national platform is a positive example. The country already came up with its 2019 report [7]. A similar platform does not exist in Ecuador yet.

However, the aforementioned 38 indicators are identified to measure the progress in achieving the global targets of the Sendai Framework and related SDGs, and determine global trends in the reduction of risk and losses. The indicators reflect the seven global targets shown by Figure 1. The global targets A-D are clearly output-oriented:

- Global target A: "Substantially reduce global disaster mortality by 2030, aiming to lower average per 100,000 global mortality between 2020-2030 compared with 2005-2015."

- Global target B: "Substantially reduce the number of affected people globally by 2030, aiming to lower the average global figure per 100,000 between 2020-2030 compared with 2005-2015."

- Global target C: "Reduce direct disaster economic loss in relation to global gross domestic product (GDP) by 2030." 
- Global target D: “Substantially reduce disaster damage to critical infrastructure and disruption of basic services, among them health and educational facilities, including through developing their resilience by 2030."

On the contrary, the global targets E-G and related indicators aim at inputs which are supportive to achieve the desired outputs of the Sendai Framework:

- Global target E: "Substantially increase the number of countries with national and local disaster risk reduction strategies by 2020."

- Global target F: "Substantially enhance international cooperation to developing countries through adequate and sustainable support to complement their national actions for implementation of this framework by 2030."

- Global target G: "Substantially increase the availability of and access to multi-hazard early warning systems and disaster risk information and assessments to the people by 2030."

This paper aims at improving the validity of the global monitoring approach which is in its current design inappropriate to identify the root causes of vulnerability and risk, but also factors for success and failure in regard to the output targets A-D. We want to derive lessons learned out of a comparative analysis between the two Latin American countries, Chile and Ecuador, which can be used for assessing and ultimately improving the performance of the current global monitoring approach. For this purpose, an indepth look at specific contexts and their governance arrangements is required. These two countries share a similar risk profile (they are part of the Pacific Ring of Fire), but differ considerably in regard to disaster risk management and are, at the same time, rarely addressed by international literature (in particular Ecuador). Specific attention is spent on the largest metropolitan regions of Quito and Santiago de Chile due to their hazard profile and considerable vulnerability as economic powerhouses of their countries, but also their outstanding disaster risk management capacities [7]. The paper is guided by the following research questions:

- What are the root causes of vulnerability and risk in Chile and Ecuador?

- How do these two Latin American countries perform in regard to the aforementioned global output targets E and G?

\section{State of the Art in Multi-Risk Assessment and Management}

Concepts for assessing risk from a spatial perspective were first developed by geographers in the 1970s [8]. This was first dominated by a focus on mapping hazards ('hazards of place') and risks. However, as Cutter [8] noted, further methodological elaborations on this subject have only rarely been attempted until the mid-1990s. It is due to authors like Burby [9] or Godschalk et al. [10] that the important role of land-use planning, and how it plays in the whole disaster management cycle, was highlighted. The other important contributor to risk management strategies is the emergency management. Its role is expressed by the capacity to cope with an extreme event. However, the actions of these two spheres are in many cases separated from each other and are characterized by a lack of common objectives and strategies [11,12]. Nonetheless, both actors-being responsible for managing the land-use of a certain area and protecting an area against any kind of threat-share the understanding that disaster risk management requires a multi-risk perspective $[13,14]$. This calls for a multi-risk assessment which "determine the total risk from several hazards either occurring at the same time or shortly following each other, because they are dependent from one another or because they are caused by the same triggering event or hazard; or merely threatening the same elements at risk (vulnerable/exposed elements) without chronological coincidence" [15]. Multi-risk is also an issue in the Sendai Framework for Disaster Risk Reduction, which propagates disaster risk reduction practices "to be multi-hazard and multi-sectoral, inclusive and accessible in order to be efficient and effective" [1] (p. 10). 
Opposite to the well-established assessment of single hazards and risks, this kind of assessment looks at the interdependencies of the occurring hazards and requires a consideration of cascading effects, even outside the exposed area. Coinciding hazards can result in cumulative and cascading effects meaning that one hazard can follow up with subsequent hazards with bigger impacts and, in total, accumulate negative effects. However, multi-risk perspectives are not systematically addressed among disaster risk management approaches and single-hazard maps are still the decision support tool most often used [16]. A multi-risk management calls for decisions in land-use planning on tolerating or altering these interactions and selecting appropriate mitigation measures. Assessing multi-risk is rather complex and still remains a challenge. A detailed multirisk assessment is connected to the difficulty of quantifying all kinds of scenarios and working with a large data amount meaning that technical standards are required and needed data are made available. Challenges of assessing multi-risks occur because of the interdependencies of sectors and related communication channels, and require multi-risk governance [17].

There is also an ongoing discussion on transformative resilience focusing on a system's capacity to adapt or transform in the face of emerging multi-risks to support sustainability $[18,19]$. For its application in the practice of disaster management and urban sustainability, building resilience for reducing vulnerability needs flexibility, learning and change [20] as well as a participatory and inclusive approach allowing vulnerable individuals and groups to play an active role in determining how best to avoid hazards and build capacity and, ultimately, just cities [21]. These theoretical discussions on sustainability and resilience clearly underline the importance of community-based strategies which are tailor-made to specific legal and cultural contexts.

\section{Methods}

Since our paper aims at a better understanding of the causing factors of the given performance of the two countries Chile and Ecuador in regard to the global output targets A-D, we focus on the input targets $E$ and $G$ and related indicators which address the national as well as local levels (that is why target F on international cooperation is not addressed by our study).

The national performance regarding these seven input indicators (see below) is to be reported to UN-ISDR annually in quantitative numbers (see the Global Assessment Report 2019 [4]). However, these input indicators neither really explain the root causes of disaster nor do they correlate with the observed disaster impacts addressed by the global output targets A-D. For the understanding of the underlying reasons of why a country fails or succeeds in disaster risk management, a deeper look at the methods, procedures and tools is required which have been used in context of disaster risk assessment and management [22]. Our paper therefore specifies, from within the seven input indicators of the global targets $\mathrm{E}$ and $\mathrm{G}$, the following guiding questions (marked in italics):

- E-1: Number of countries that adopt and implement national disaster risk reduction strategies in line with the Sendai Framework for Disaster Risk Reduction (DDR) 2015-2030:

- Did Chile and Ecuador adopt national strategies?

- E-2: Percentage of local governments that adopt and implement local disaster risk reduction strategies in line with national strategies:

- Have Chilean and Ecuadorian cities adopted local DRR strategies? Are the output targets $A-D$ addressed by these strategies and if yes, how?

- G-2: Number of countries that have multi-hazard monitoring and forecasting systems.

- Do Chile and Ecuador have such a system in place?

- G-3: Number of people per 100,000 that are covered by early warning information through local governments or through national dissemination mechanisms. 
What is the diffusion rate of early warning systems in Chile and Ecuador? For which hazards are these systems established?

- G-4: Percentage of local governments having a plan to act on early warnings.

To what extent do emergency management plans exist at the local level in Chile and Ecuador? Do they include preparedness and response strategies based on early warnings?

- G-5: Number of countries that have accessible, understandable, usable and relevant disaster risk information and assessment available to the people at the national and local levels.

Is this kind of information available in Chile and Ecuador on the national level? Does an evidence basis for multi-risk assessment exist at the local level?

- G-6: Percentage of population exposed to or at risk from disasters protected through pre-emptive evacuation following early warning.

- Have evacuations been effectively used in Chile and Ecuador? If yes, for which types of events?

Data on the performance of both countries were not gathered from the incomplete global UN-ISDR database, but a desk-top analysis of national policy documents and strategies from Chile and Ecuador as well as local risk management and land-use plans from Quito and Santiago de Chile.

Further, primary data for an in-depth evaluation of context-specific assessment and management strategies were collected during a field trip and two workshops in Ecuador. The first one took place on 22 November 2019 in Latacunga with representatives of the provincial departments of spatial planning and emergency management, and the municipality of Latacunga (departments of land-use planning, emergency management, environment, housing and water management). A second workshop was organized in Quito in the evening of the same day with representatives from several governmental agencies (Ministerio de Desarrollo Urbano y Vivienda (MIDUVI, Quito, Ecuador), Secretaria Tecnica Planifica Ecuador (STPE) (former SENPLADES, Quito, Ecuador), Ministerio del Ambiente y Agua (MAE), Servicio Nacional de Gestión de Riesgos y Emergencias (SNGRE) (former SNR), Concejo Nacional de Competencias (CNC), Superintendecia de Ordenamiento Territorial (SOT), Instituto de Investigación Geológico y Energético (IIGE, Quito, Ecuador) and the NGO Grupo Faro, Quito, Ecuador.

The workshop planned for November 2019 in Santiago de Chile had to be cancelled due to the violent political unrest which Chile experienced from October 2019 till early 2020. After that, physical meetings were not possible due to the COVID-19 pandemic.

In addition, we conducted expert interviews with stakeholders from various agencies in order to validate our empirical findings in both countries. In Ecuador, the two interviewees were representatives of the national spatial development authority (Dirección Nacional Técnica y Planificación/Asociación de Municipalidades Ecuatrianas, AME, Quito, Ecuador) and disaster risk management (Asociación de Profesionales de Gestión de Riesgos del Ecuador, APGRE). In Chile, we interviewed one representative from the national emergency office (ONEMI, Santiago, Chile).

\section{Case Studies}

\subsection{Chile}

Due to its geographical position in the Pacific Ring of Fire and its latitudinal extension of about $4300 \mathrm{~km}$, Chile is exposed to a great diversity of climates and extreme natural events as earthquakes, volcanic eruptions, droughts, intense rainfall, floods and landslides (see Figure 2). From these, the hydro-meteorological events have become the most frequent in recent years. However, earthquakes and tsunamis have a history of greatest damage, in terms of fatalities and economic impacts [23]. 


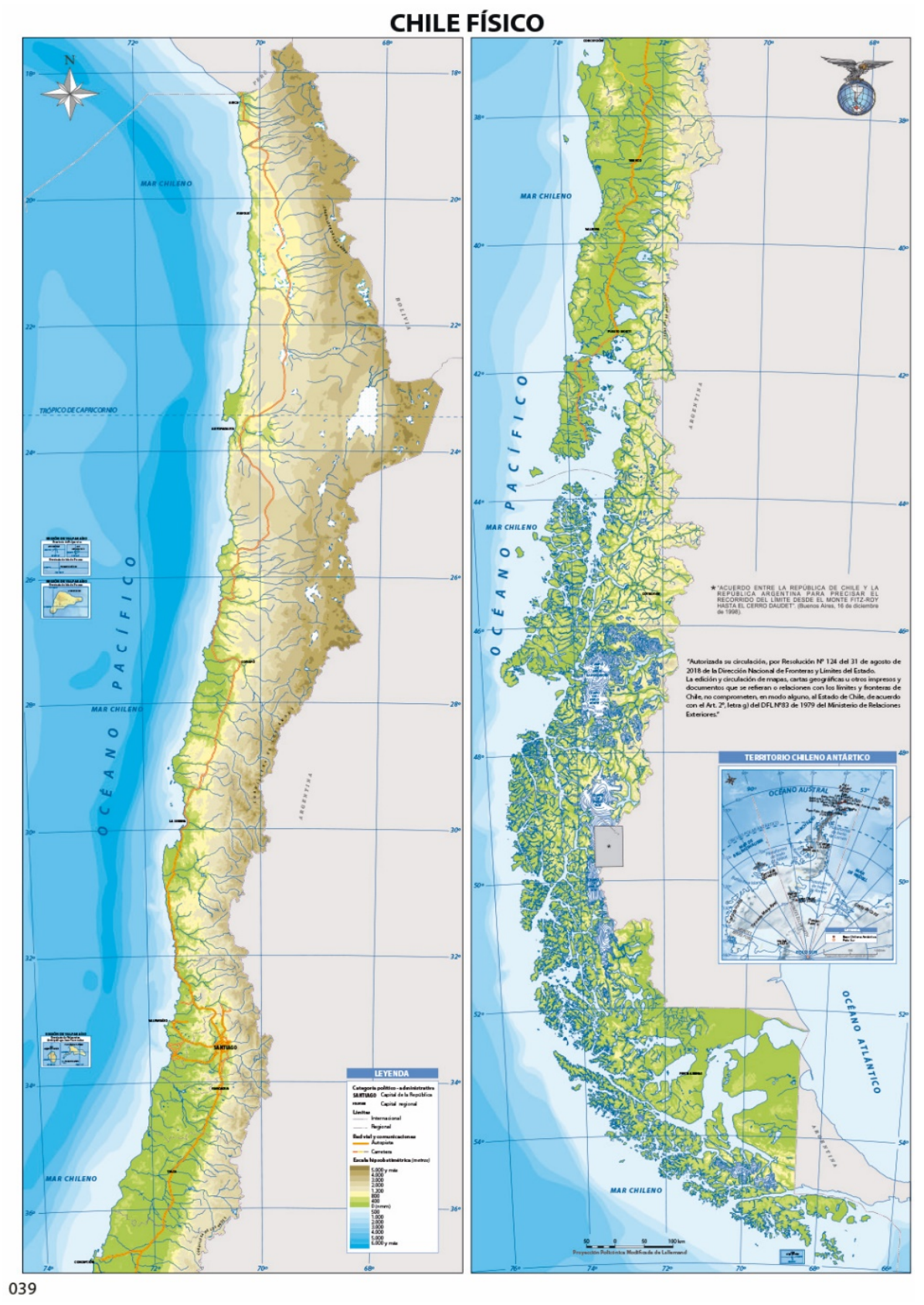

Figure 2. Geophysical map of Chile.

As in the rest of Latin America, Chile has a high level of urbanization with almost 90\% [24] of its population living in urban areas. This urbanization, product of a rapid and unplanned growth, occupied hazard prone areas and recreated the unequal and exclusionary shape of Chilean society in the spatial distribution of human settlements [25].

This country has experienced a strong economic growth in the recent decades, but the benefits from this progress have not been equally distributed across society, but rather concentrated in the wealthiest sectors of society [26]. Thus, inequality might be the main vulnerability to risk in Chile; which is so high and deeply rooted, that it can be seen as the core reason of the social outbreak that began in October 2019. Inequality that generates different levels of exposure to risk among the different segments of society affects the poor harder and with longer impacts.

Additionally, the Chilean DRR system is neither comprehensive nor participative. In general, the population is excluded from the planning processes and is only consulted to validate decisions. Despite all this, Chile is a regional leader in terms of its low physical 
vulnerability due to the effective and wide implementation of the earthquake resistant building code [27]. Moreover, in recent years, the study and monitoring systems are improving by generating timely and more characterized risk information; and decentralizing and giving strength to the early warning and monitoring systems at regional level [28].

Despite the fact that the cities of Santiago (about 7 million inhabitants) and Valparaíso (1.8 million) integrate several communes, metropolitan administration does not exist in the political-administrative structure of the country. Santiago, as a commune, is the capital of the country and of the "Metropolitana" region. Located in the foothills of Andes mountain range, Greater Santiago is made up of 36 communes and is affected by earthquakes and flooding throughout the entire city, and by landslides and heavy rainfall in certain communes near the mountains. Here, earthquakes have left the most expensive damage [29]. The commune of Valparaiso is the capital of the homonymous region. Greater Valparaiso is made up of 8 communes. Located in a bay surrounded by an amphitheater of hills that descend towards the Pacific Ocean, it has been historically exposed to earthquakes, tsunami, heavy rainfall, landslides and forest fires. Both cities have similarities in terms of urban growth patterns and vulnerabilities, like the occupation of hazard prone areas, deep inequality and segregated poverty that constrains the capacity of the population to own worthy housing. This is reflected in the poor quality of construction in Santiago [30] and large sectors of informal settlements in Valparaíso [31]. It should be noted that by 2018, it was estimated that there were 741 informal settlements (campamentos) in Chile, inhabited by 43,000 families. In the Valparaíso Region were 188 informal settlements with 11,150 families, and in the Metropolitan Region were counted 84 informal settlements with 4214 families [32].

Both cities are managed at two levels: locally, by a municipality for each commune that makes up the city, and by the regional government within which each city belongs. In practice, the regional level assumes a comprehensive role for each city in terms of disaster risk reduction, while the local level historically had a prominent role in land-use planning. Regarding land-use, it is expected that each level generates their respective plans for land-use, using the "Guide for the Analysis of Natural Risks for the Land-Use Planning" [33] that includes a disaster risk management (DRM) perspective. For disaster risk reduction, all levels must constitute a Civil Protection Committee, which switches to Emergency Operation Committee during an emergency. These Committees are in charge to develop disaster risk reduction and emergency plans. The generic development of these plans, which lack local-based information, evidences that guidelines emanated from central level are poorly followed by regions and especially communes. Municipalities are weak institutions with low managerial capacity, economic and political power. Again, inequality determines their different access to resources. Communes with less resources and higher vulnerability designate less money per habitant for DRM actions, especially in larger population communes. Budgets are mainly focused on rapid emergency response rather than prevention actions [34].

\subsection{Ecuador}

Ecuador has four main geographic regions (see Figure 3): La Costa, or "the coast": The coastal region consists of the provinces to the west of the Andean range. It is the country's most fertile and productive land. The largest coastal city is Guayaquil. La Sierra, or "the highlands": The sierra consists of the Andean and Interandean highland provinces. This land contains most of Ecuador's volcanoes. The largest Sierran city is the capital, Quito. La Amazonía, also known as El Oriente: The oriente consists of the Amazon jungle provinces. La Región Insular is the region comprising the Galápagos Islands, about $1000 \mathrm{~km}$ west of the mainland in the Pacific Ocean.

The country is highly affected by a number of natural hazards [35]. Due to the subduction of the Nazca Plate under the South American Plate, the region shows a high seismic and volcanic risk. Furthermore, El Niño leads to heavy rainfall as well as draught periods. As a result, Ecuador also faces problems such as landslides in the mountain areas. 
Due to the high variety of natural hazards, Ecuador frequently is affected by multi-hazard events, meaning that one hazard can trigger another one, for example, an earthquake followed by landslides or a tsunami [36].

At the same time, many cities in Ecuador are facing high population growth in recent decades and an expansive, widely uncontrolled urban development, which has led to the appropriation of a vast territory with low population density. These areas typically present a high degree of inequality of services, green areas and infrastructure. Many settlements have a high vulnerability to disaster risk because they are located in highly hazardous areas [37]. Especially informal settlements are affected by this problem. As stated by the Subsecretariat of Habitat and Human Settlements [38], 88\% of the country's municipalities present some informal settlements. There are approximately 2.9 million people living in 729.291 houses located in informal settlements, which makes up almost $20 \%$ of the Ecuadorian population. About two thirds of these settlements are located in urban areas, whereas one third can be found in rural areas.

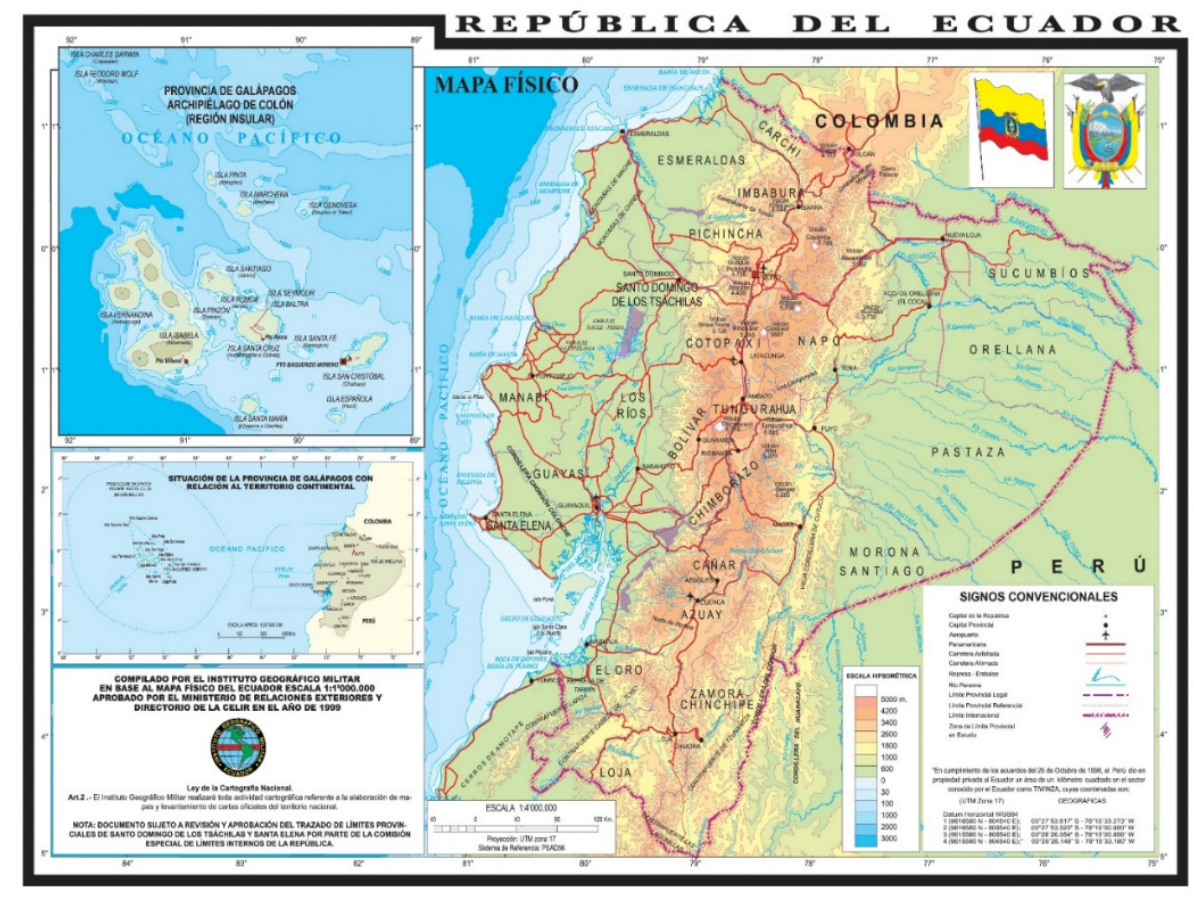

Figure 3. Geophysical map of Ecuador [39].

It was not until 2016 that Ecuador experienced a sequence of events-natural and social - that constituted a milestone in the history of DRR in the country. In September 2020, the College of Architects of Ecuador launched the Geoportal of the Quito Urban Information Centre. This innovative digital tool allows users to access georeferenced data for the entire metropolitan district of Quito, providing access to information on types of soil and mechanical properties (used mainly for hazards modeling), urban growth data, environmental services and relevant information for risk management, such as public and open spaces, immediate aid units, community police stations, medical centers, etc. [40].

Quito, as the capital city (2.8 million inhabitants), is located between the slopes of the Pichincha volcano to the west and a system of active geological faults to the east. As a particular factor, every summer it experiences heavy seasonal rains. Due to its natural condition at being crossed by four tectonic faults and surrounded by 20 volcanoes, the Metropolitan District of Quito (DMQ by its Spanish abbreviation) is exposed to multiple natural and anthropogenic threats that can directly affect the population and infrastructure located in vulnerable sectors [41]. Together, these characteristics produce a combination for multiple hazard events to occur simultaneously, including mass movements, floods, and forest fires, which are the most recurrent phenomena in the territory. However, volcanic 
eruptions and earthquakes are other manifestations of natural origin that have occurred on previous occasions and could recur. In addition, Quito is also expanding rapidly, and already by 2018, it became the largest city in Ecuador [42].

In September 2008, the municipality of Quito created the "Metropolitan System of Integral Risk Management of the DMQ and its Components". In July 2016, the municipality of Quito presented the "Quito Ready" Program which includes the axes of "Awareness", "Training", "Prevention" and "Response" to six types of natural and two human-made hazards that occur in the DMQ. In October 2017, the International Meeting "Quito: One Year after Habitat III" was celebrated. By then, the Metropolitan Disaster Risk Reduction Management Plan of Quito "Quito Listo" was presented [43]. Developed by the Quito's "General Secretariat for Security and Governance", the plan, aligned with the Sendai Framework focuses on five areas: (1) Quito understanding risk, (2) A strengthened Quito implements the Plan, (3) Quito reduces vulnerability, (4) Quito protects infrastructure and (5) Quito is prepared for emergencies. In the same year, the Plan for Prevention and Response to Adverse Events in the DMQ (floods and mass movements) was presented by the municipality.

This combination of multi-hazard risk and rapid urbanization implies that urban development inevitably coincides with hazard hotspots, placing intensifying stress on communities, infrastructure and sustainable development. Although the politics of the metropolitan government have exacerbated these risks over the last 30 years, less has been placed on regarding how disaster risk reduction can be integrated into urban development.

\section{Results}

In the following, we present our empirical results regarding the seven aforementioned global input indicators. Table 1 provides a comprehensive overview about key characteristics of both countries:

Table 1. Key characteristics of Chile and Ecuador.

\begin{tabular}{|c|c|c|}
\hline Issue & Chile & Ecuador \\
\hline \multicolumn{3}{|c|}{ General } \\
\hline Past disasters & $\begin{array}{l}\text { Earthquakes and tsunamis with greatest } \\
\text { damage, furthermore, droughts, intense } \\
\text { rainfall, floods and landslides }\end{array}$ & $\begin{array}{l}\text { Seismic (earthquake, tsunami), volcanic, } \\
\text { heavy rainfall and drought, landslides; } \\
\text { multi-hazard events }\end{array}$ \\
\hline Population, total & 19.0 million (2019) & 17.4 million (2019) \\
\hline Urban population (\% of total population) & $88 \%(2019)$ & $64 \%(2019)$ \\
\hline Urban population growth (annual \%) & $1.27 \%(2019)$ & $1.93 \%(2019)$ \\
\hline Informal settlements & $\begin{array}{l}741 \text { informal settlements, populated by } \\
\text { 43,000 families (2018) }\end{array}$ & $\begin{array}{l}88 \% \text { of municipalities with informal } \\
\text { settlements with } 2.9 \text { million inhabitants } \\
\text { (20\% of population) }\end{array}$ \\
\hline
\end{tabular}

The following Table 2 sums up the relevant results in regard to the global input indicators $\mathrm{E}$ and $\mathrm{G}$ :

Indicator E-1. Did Chile and Ecuador adopt national disaster risk reduction strategies in line with the Sendai Framework for Disaster Risk Reduction 2015-2030?

In Chile, the Sendai Framework for Disaster Risk Reduction was adopted in 2015, in accordance with the 69/283 resolution. The National Emergency Office (ONEMI) has the mandate of monitoring the implementation of the Sendai Framework. For this, it coordinates with the Social Development Minister (in charge of the Agenda 2030 implementation) and the National Institute of Statistics. The three main national tools that guide, implement and promote disaster risk reduction strategies are the National Policy for Disaster Risk Reduction (PNGRD) [44], the National Strategic Plan for Disaster Risk Reduction 2015-2018 (PENGRD) [45] and the National Platform for Disaster Risk Reduction. 
Table 2. Similarities and differences between empirical results from Chile and Ecuador [own elaboration based on various sources (see text below)].

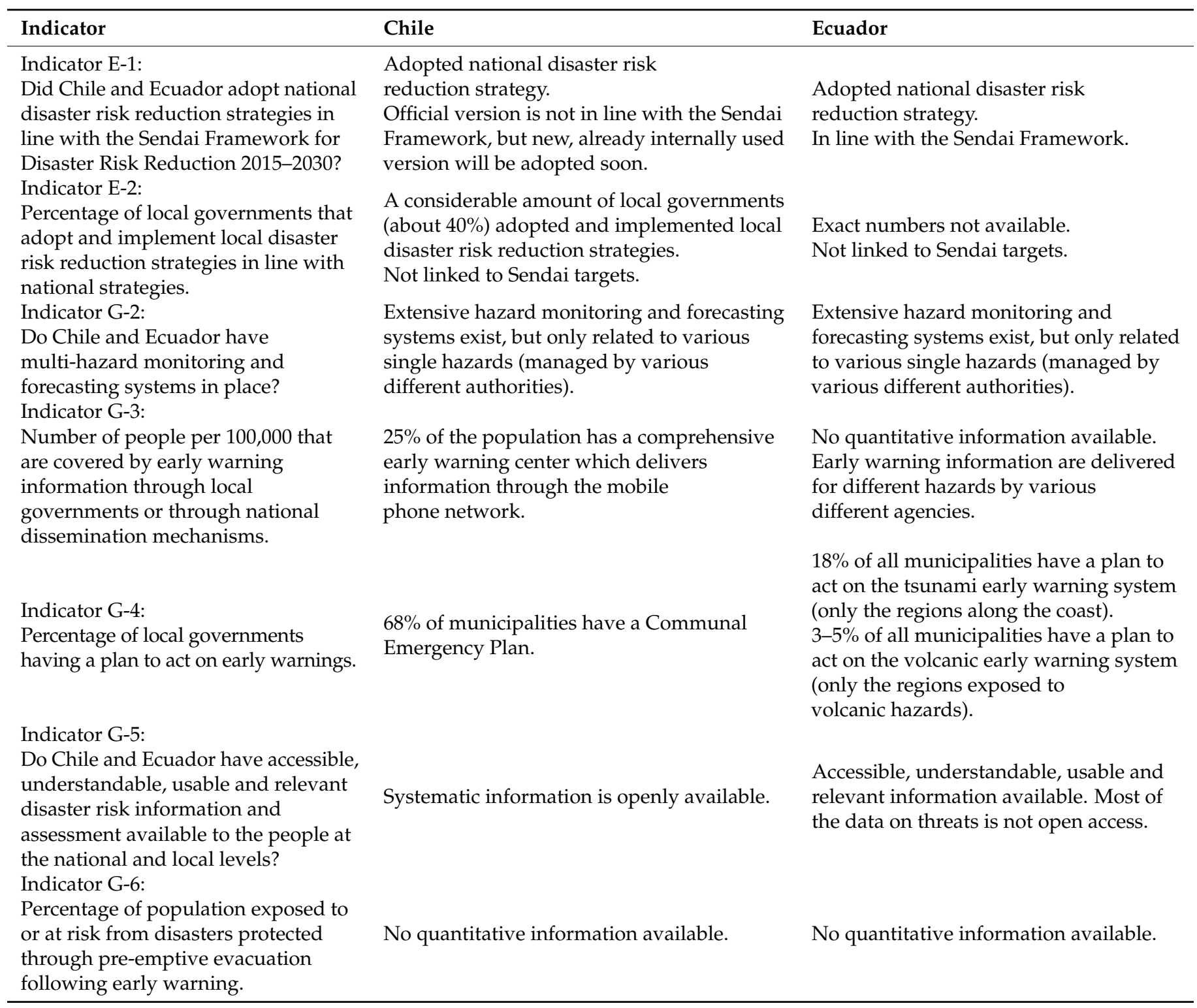

The publicly available PNGRD was presented in 2014, and approved in 2016. It aligns its main strategic axes and objectives with the main axes of the Hyogo Framework of Action. The PENGRD began its formulation in 2014, aligning to the 26 national policy objectives as well as to the Hyogo Framework respectively. It proposes 84 strategic actions for the period 2015-2018. The PENGRD has not been updated to the Sendai Framework yet.

A new PNGRD, aligned to the Sendai Framework goals, is in use since 2019 among the agencies that integrate the national platform for DRR, and will be in force until 2030. This new policy has not been officialized or promulgated yet. In order to be published, this policy needs to be approved by the General Comptroller of the Republic [46].

On the other hand, the National Platform for Disaster Risk Reduction was formed up in 2012. However, it was not formally constituted with its respective regulation until 2015. The platform is an advisory body of the National Emergency Office (ONEMI), that seeks to establish and promote DRR at all levels. Nonetheless, it changed its regulation in 2018, where under consideration of the Sendai Framework for DRR, sets as one of its specific objectives to "ensure the coherence of international instruments, whatever their 
nature, relating and integrating into national sectoral instruments". Despite this fact, this is the only public mention where the National Platform considers the Sendai Framework; according to our findings, there is a Chilean Sendai Network within the platform, which monitors the Sendai indicators' compliance. This network is confirmed by representatives of the ministers and public services.

In August 2019, Ecuador formalized the "National Agreement for Disaster Risk Reduction 2030" [47]. Composed of five thematic axes, the agreement foresees promoting prior approval, the enforcement of the "Law of the Organic Code of State Security". Heading towards adopting national DRR strategies, the thematic axes include:

1. Incorporating disaster risk management into national and local planning.

2. Promoting of the "Law of the Organic Code of State Security" and its chapter "Decentralized national system of risk management".

3. Controlling the accountability of the Ecuadorian Construction Standard (NEC).

4. Building financial mechanisms for disaster risk management.

5. Agreeing to public-private actions for disaster risk management.

In 2019, SNGRE (Servicio Nacional de Gestion de Riesgos y Emergencias-National Service for Risk and Emergency Management) published its updated "Specific Strategic Plan for Disaster Risk Management 2019-2030" (PEEGRD) as a short, medium and longterm planning instrument thought to guide actions at all levels of government through the “National Decentralized Risk Management System" [48].

In addition, in the PEEGRD, other instruments for land management and land-use (in the area of planning), are worth highlighting. Although the Organic Law on Land-Use and Management (LOOTUGS) does not make a direct reference to DRR, it prescribes that local governments must identify natural and anthropogenic hazards within their territories. It is through the land-use and management plans, particularly through the "Territorial Intervention Areas" (PITs) that strategy number 5 of the PEEGRD finds correspondence. However, in the absence of a system to monitor and evaluate the cross-cutting nature of the implementation of these actions, it is not possible to indicate how effective these national initiatives are and/or will be.

In 2019, the Technical Secretariat "Planifica Ecuador" (STPE) published, in a collaborative effort with SNGRE, a guideline for the formulation/update of PDOTs (Guidelines for the inclusion of disaster risk management in the Development and Territorial Planning Plan). While such guidelines came as a series of efforts to land the executive's instruments though sectoral scopes (digitalization, participation, climate change, risks, etc.) to the administrative levels (GAD), SNGRE's guideline addresses the aspect of "Strategies to guarantee the progressive reduction of risk factors or their mitigation, from the central government". However, while such guiding documents are thought to aid PDOT formulation, GADM (the local administrative units) are free to choose whether to use these, to concentrate their views on one or some, as well as to pick discretionally some of their contents.

Indicator E-2. Percentage of local governments that adopt and implement local disaster risk reduction strategies in line with national strategies

In Chile, ONEMI proposes a specific format for the territorial units (national, regional, communal) to prepare their respective Disaster Risk Reduction Plans [46]. According to the findings of our interview, ONEMI reports a high percentage of municipalities that have DRR plans, but with different levels of development. However, ONEMI does not monitor the progress of the municipalities in the preparation of these plans. The development of these plans is voluntary. Additionally, not all of them are aligned with the Sendai Framework.

Additionally, the "Natural Hazard Analysis Guide for Land-Use Planning (SUBDERE) is also used by local governments to develop their respective plans, but it was prepared prior to the Sendai Framework, so it does not include such indicators. The Chilean Association of Municipalities (AMUCH, Región Metropolitana, Chile) conducted the cadaster of municipal capacities for Disaster and Emergency Risk Management in which a national- 
wide sample of 247 municipalities was counted, equivalent to $70 \%$ of all local governments. According to this report, $87.2 \%$ of the municipalities in the sample declared that they have a unit in the municipal organization dedicated specifically to disaster risk management [49].

However, there are great differences in relation to the capacities that these offices have in each municipality. Using a commune's development typology from SUBDERE (the "Natural Hazard Analysis Guide for Land-Use Planning"), it appears that between large metropolitan communes with high and/or medium development, $28 \%$ have a Risk Management Directorate (with their own resources) and $45 \%$ have an Office or Department. On the other hand, among semi-urban and rural communes with low development, $48 \%$ have an Office or Department, while 36\% have only one person in charge of the subject. The AMUCH study indicates that of the sample [49]:

- $\quad 41.8 \%$ of the municipalities have a Community Plan for Civil Protection and Emergencies in force,

- $\quad 31.2 \%$ consider aspects related to disaster risk management in their respective Community Regulatory Plans,

- $\quad 24.9 \%$ declare that they have a specific management plan for disaster and emergency risk reduction,

- $\quad 48.3 \%$ have an exclusive budget to carry out actions in disaster and emergency risk management.

In Ecuador, the GADMs have adopted local DRR strategies based on mainly three instruments:

1. "Cantonal Emergency Plans" (CEP); mainly response plans.

2. "Risk Reduction Agendas" (RRA); focused on transport infrastructure (sea and river ports, bridges, roads, land terminals) and water (water sources).

3. "Risk Management Units" (UGR); mainly preventive, created by municipal decree and if existing, with multiple constitutional and financial allocation variation.

The first two, pushed from the central government are mainly specific and vary from GADM to GADM. Currently, not all GADMs have CEP and/or RRA. In the case of UGR, these are pushed by the GADM and are directly connected to the mayor's office. Currently, not all GADM have UGR.

It can be expected that through the "Guidelines for the inclusion of disaster risk management in the Development and Territorial Planning Plan (PDOT)", GADM will consider DRM as a transversal axis, inherent to planning and development plans. The degree of such inclusion is to be seen; exact numbers are not available. While PDOTs were originally foreseen to be submitted to STPE by March 2020, a new deadline, due to COVID-19, has been set towards the end of 2020. On the other hand, and in the spirit of a bottom-up strategy and monitoring, there is an initiative from the private sector, namely from the "Association of Risk Professionals" (together with SNGRE, the Association of Municipalities of Ecuador and INEC) of developing a "Risk Management Index" that can be adjusted to the GADs' competencies and monitored within the GADM's institutional setup (and budget). While this initiative may unquestionably strengthen the relevance of DRR, it misses the leverage of the UGR's empowerment as an institutional option from within the local and municipal constituencies.

The "Guidelines for including DRM in the PDOT" refer to the Sendai Framework but are not necessarily linked to targets $A, B$ and $C$. In the case of D, the PEEGRD could be considered as the National Strategy. Several of the strategies from both PEEGRD and the "Guidelines for including DRM into PDOT" have so far been reflected in response preparations (mainly simulacrum and public awareness campaigns).

Indicator G-2. Do Chile and Ecuador have multi-hazard monitoring and forecasting systems in place?

Chile does not have multi-hazard monitoring and forecasting systems. However, the Early Warning Center (CAT) gathers information from the reports of different technical 
bodies of the National Civil Protection System, to create alerts per hazard. Thus, different hazards are monitored and forecasted by different technical bodies at national level [50].

- The Hydrographic and Oceanographic Service of the Navy (SHOA) monitors the risk of tsunami.

- The National Seismological Center monitors earthquakes.

- The National Service of Geology and Mining (SERNAGEOMIN) monitors geological and volcanic risks.

- $\quad$ National Forestry Corporation (CONAF, Santiago, Chile) monitors the risk of forest fires.

- The Chilean Meteorological Directorate monitors and forecasts all weather events at national level.

In Ecuador, the National Information System (SNI), which was introduced in 2008, is responsible for coordinating risk assessment. It provides inputs and basic cartography that allow planning of the territory. To fulfill this task, the SNI works together with different institutions, which conduct research on their respective field of expertise. They estimate and evaluate risk, observe and analyze disasters, and develop hazard maps.

Due to the fact that the development of hazard maps is the responsibility of different institutions, depending on the kind of hazard, there are no defined standards for their elaboration. Most institutions are in charge of single hazards, so the hazard maps are usually single-hazard maps and do not consider multi-hazard effects.

The tsunami and flood monitoring system at national level has advanced substantially, but is not articulated into a unitary system. Monitoring and evaluation is done separately by INAHMI (Instítuto Nacional de Meteorología e Hidrología, Quito, Ecuador), CIIFEN (Centro Internacional para la Investigación del Fenómeno de El Niño, Guayaquil, Ecuador), INOCAR (Instítuto Oceanográfico de la Armada, Guayaquil, Ecuador), IIGE (Instítuto Geofisico) and Ecu911 (emergency call number). Some impulses towards integration have been observed from the Ecu911, even though these exceed its competences, questioning its long-term sustainability. Ecuador has experience in evaluating susceptibility to mass movements with various methodologies and scales, mainly on a specific basis. Efforts at the national level include those between the IIGE and the SNGRE where the susceptibility to mass movements was zoned at the national level on a scale of 1:50,000 and 1:25,000 (2014). Susceptibility maps by IIGE were published for the provinces of Chimborazo and El Oro at a scale of 1:50,000 (2013) and a Susceptibility Map at a scale of 1:1,000,000 (2014). Monitoring is reflected mainly in punctual situations and rendered as diagnostic.

Indicator G-3. Number of people per 100,000 that are covered by early warning information through local governments or through national dissemination mechanisms

In Chile, the Early Warning Center (CAT) is the unit within the National Emergency Office that makes a constant monitoring in real time of the national territory, and disseminates the alerts to the Civil Protection System. It heads and manages an informational system that receives reports and demands from the National Civil Protection System. Thus, it manages monitoring through the Regional Early Warning Centers and the different technical bodies of the National Civil Protection System. The presence of these Regional Early Warning Centers is fundamental to keep an interlinked system, in coordination with the National Early Warning Center [51].

The alerts that CAT makes can be declared for one or more communes, provinces or even regions across the national territory. The number of resources, services and organizations involved varies according to the coverage of the alert. The CAT makes alerts for surge, tsunamis, earthquakes, volcanic activity, mass movement, geological risk and forest fires. It uses four types of alerts: Green Alert, Early Preventive Alert, Yellow Alert and Red Alert. The early preventive alert is used before the Yellow Alert to strengthen monitoring to possible emergency situations.

Besides this, the Emergency Alerts System (Onemi, Santiago de Chile, Chile), is supposed to send alerts (text, audio and vibration) to all mobile phones in the country 
in case of risk to tsunami, high magnitude earthquakes, volcanic eruptions and forest fires. The SAE is implemented by Onemi with the support of the Telecommunications Subsecretary. This massive alert is automatically sent to a georeferenced area according to the alert. In reality, the system has been implemented since 2014, but is only available for approximately $25 \%$ of all users of mobile phones [52].

In Ecuador, at the national level, there is no information on the dissemination rate of early warning systems. In the case of "tsunami", it is presumed that at least the entire population along the coastal profile enjoys information reported by INOCAR. Its work is relevant for tsunami risks, especially by producing vulnerability studies in coastal areas, flooding maps, and identification of potential risk zones. It aims to establish a National Tsunami Alert System to minimize human and economic losses caused by tsunamis.

Moreover, the Instítuto Geofísico de la Politécnica Nacional (IGEPN, Quito, Ecuador) is responsible for the continuous observation and scientific investigation of seismic and volcanic hazards and the development and application of prevention technologies. It develops hazard maps for volcanic areas.

Finally, the Instítuto Nacional de Meteorología e Hidrología (INAMHI, Quito, Ecuador) generates and distributes hydro-meteorological information relevant for the national development.

\section{Indicator G-4. Percentage of local governments having a plan to act on early warnings}

In Chile, the early warning system operates on a national level. The National Early Warning Center corresponds to a critical unit within ONEMI, which has decentralization at the regional level. This unit is in charge of establishing and disseminating early warnings within the civil protection system at any level. Therefore, at the local level, there are no specific early warning plans.

In 2019, 68\% of Chilean municipalities have informed ONEMI [53] that they have a Communal Emergency Plan, which, through standardized formats provided by ONEMI, must indicate how local capacities, endowment of human and technical resources, and materials necessary to face an emergency in its territory are coordinated. It is worth mentioning that between different regions there are differences as to whether or not the communes that compose them have an Emergency Plan. On the other hand, there are communes that have specific emergency policies by threat variable.

The emergency plans include concept definitions on preparedness and response strategies based on early warnings, but no proper strategies suited to every local context.

It is estimated that in Ecuador, out of the 221 municipalities (total), only those along the coastal profile (incl. Galapagos) (no. of municipalities: $40,18 \%$ ) have a plan to act on the tsunami early warning system [54]. In the case of the volcanic threat (volcanic eruptions), it is estimated that only the exposed regions have a plan to act, namely: Cotopaxi: (no. of municipalities in the influence region: $\sim 8-10, \sim 3-5 \%$ ) and Tungurahua: (no.: $\sim 12, \sim 5 \%$ ).

For earthquakes, there are seismographs at the provincial level located along the most important faults, such as Quito and Puna-Pallatanga, etc.; they do not necessarily contribute to an early warning system, but rather report on earthquakes that have occurred.

Although a change in the risk paradigm is recognizable, emergency management plans at national and local levels are mainly available for single critical infrastructures (such as airports, electricity and water supply), and hazardous industries (chemical production, waste deposits).

Indicator G-5. Do Chile and Ecuador have accessible, understandable, usable and relevant disaster risk information and assessment available to the people at the national and local levels?

In Chile, there is systematic information available in relation to risk management strategies and plans at the national, regional and local levels. The national and regional levels of information are available through the ONEMI's website [55]. Although ONEMI works with updated disaster risk information that is aligned to the Sendai Framework, this has not been disseminated yet, as it waits for the approval of the new PNGRD and its consecutive instruments. ONEMI lacks comprehensive actions for all DRRM processes, as 
it focuses mainly on emergency response. Additionally, it lacks resources and knowledge to lead the DRM system nationwide [27]. Meanwhile, the local-level information is available through each municipality website. Nevertheless, as the information and plans respond to national standards, it may lack an in-depth analysis of the local situation, which can make it irrelevant in some cases.

Additionally, the "Chile Preparado" viewer aims to become the national-level tool to inform about the volcanic, tsunami and forest fire risks. Thus, the viewer does not add a complete multi-risk perspective. Even though it is a national-level tool, it manages information for the local level. It is accessible to everyone and with available information to be downloaded for private use. Its main objective is to be used by the community for their preparation actions towards these threats. It includes information about roads, topography, location of schools and educational centers, health centers, firefighters, police, and the state of border crossings; as well as evacuation areas, meeting points and evacuation routes in the event of a tsunami threat, and meeting points in the event of a volcanic threat [56].

According to objective 2 of the Institutional Strategic Plan, in Ecuador, the SNGRE aims to increase the culture of risk management in the citizenry. Strategies were developed, like the encouraging of training and participation, the generating of spaces for citizen participation or the promotion of knowledge and awareness of risk.

Ecuador has accessible, understandable, usable and relevant information available, mainly in terms of communication material. On the other hand, it is important to underline that most of the data on threats is not necessarily of open access. Upon request, the obtained information is codified by the issuing organization. In addition, available data is of descriptive nature and it is missing an analytical scope (possible reason for which PDOT also limits their scope on risk by limiting to the description of hazards).

The website "Ecuador listo y solidario" provides understandable information about volcanoes, tsunamis, inundations, earthquakes, wildfires and mass movements and gives recommendations about how to act in case of a disaster [57].

There is a national cadastral base at 1:1000. The vast majority of GADM has a record on past events. About 75 GADM (out of the 221) have created their respective UGR and about only 12 have begun to incorporate the "risk" component in their PDOTs and landuse and management plans as a development mechanism (e.g., Cuenca, Portoviejo, Loja, Riobamba, Ibarra, Ambato, Salinas and Machala).

Indicator G-6. Percentage of population exposed to or at risk from disasters protected through pre-emptive evacuation following early warning

In Chile, information is not available or does not exist in relation to the percentage of the population exposed to risks protected by preventive evacuation. ONEMI has evacuation plans for communes and/or risk areas [58]. In addition, it has general plans for kindergartens and educational establishments, although they lack depth. Evacuation drills are held periodically in different communes, according to the type of risk present (tsunami, earthquake, volcanic eruption) [59]. There are successful cases of evacuation (Coquimbo Earthquake and Tsunami 2015) and cases where evacuation failed disastrously (Maule Earthquake and Tsunami 2010).

In Ecuador, no data are available at the national level. SNGRE has certified the identification of evacuation routes, safe zones, etc., but at the GADM level, there is, overall, no linkage and/or coordination with other local, provincial and national authorities in terms of the layout of roads and critical infrastructure.

\section{Discussion}

Chile and Ecuador share similar hazard profiles, which explains the observed similarities regarding the risk assessment approaches. Both countries have specialized technical institutions for monitoring and forecasting specific risks, and maintain freely accessible information regarding disaster risk at the national level. 
From a political-administrative perspective, both countries have centralized governments. Disaster risk management is organized through a top-down approach, which means that the local level does not possess self-governed rights. Both countries have conducted instructions to foster and ensure the inclusion of DRR perspective in local plans, in line with national strategies. Nonetheless, only the existence of guidelines to include DRR perspective could be insufficient, considering the technical and financial limitations that most of the local-level administrations deal with. As Valdivieso and Andersson argued [60], a deeper understanding of disaster risk management performance requires multiple dimensions and factors. Specific local institutional arrangements and relationships between actors such as municipal councils and institutional actors at other governance levels, such as regional governments, ministries, and NGOs, play a decisive role for the quality of risk management schemes. Both countries widely disregard public participation and risk communication which are highly acknowledged as key elements of risk assessment [61] as well as management $[62,63]$. This is a key root cause for the given vulnerability. Another shared key vulnerability factor is the considerable amount of informal settlements in hazard prone areas and consequently, the attention of both national government's spending to resettlement schemes [64,65].

Although this applies for most of the countries, it is a significant drawback that in countries like Chile and Ecuador that are characterized by multi-risk profiles, this perspective is not yet established and none of the countries has a robust and consolidated strategy in relation to multi-risk monitoring and management $[23,35]$ and cascading effects of disruptions of infrastructure services [66]. However, the recognition of critical infrastructure is becoming relevant, especially after the latest disaster events such as the 2010 earthquake in Chile [67] or the Rio Coca Erosion vis a vis the Central Hidroeléctrica Coca Codo Sinclair + oleoductos in Ecuador [68], but it is still necessary to advance towards a precise definition of what the term refers to, and above all, to a comprehensive analysis of criticality in the face of multi-risk scenarios and cascading effects.

Climate change as a trigger for hydro-meteorological extremes is well acknowledged in both countries $[69,70]$. Climate change adaptation surely stimulated the political attention to extreme events. Disaster risk management can considerably support adaptation to climate change and vice versa [71], but it has to be noted that the existing fundamental differences between CCA and DRM are widely ignored by the key policy documents in Chile and Ecuador. While disaster risks are normally probabilistically assessed by means of statistics from past events that inform hazard and risk maps, climate change impacts are always scenario-based, and project potential future, deeply uncertain changes of extremes, but also creeping changes of the climate and, subsequently, the environment [72].

Both countries mainstream disaster risk management into land-use planning. Landuse planning is especially important in the phase of prevention, which aims at a reduction of damages to people, property, and resources before a disaster strikes [73]. Further, spatial planning can also play an important role in the phase of reconstruction in the aftermath of a disaster by taking care of a better and more sustainable reconstruction of cities and human settlements (e.g., the principle of "build back better") [1].

A particular strength in Chile is the advanced disaster risk preparedness and response, combined with its well elaborated building standards [20]. Moreover, a common procedural framework for the territorial levels for the analysis and management of disaster risk is in place, which means, on the contrary, that risk reduction and management plan formats are, in some cases, not adequately adjusted to the local situation. Chile owns also a high response capacity at the middle and high levels of the administrative structure which makes it possible to fill the existing gaps in the local units. Nonetheless, there are some weaknesses. The national strategies are not yet aligned to the Sendai Framework.

The central level of administration holds most of the trained professionals and capacities to train personnel in DRR [74]. Moreover, in recent years, the study and monitoring systems are improving and strengthening the early warning and monitoring systems at regional level [28]. The largely varying resources between municipalities lead to fundamen- 
tal differences regarding the implementation of disaster risk management and reduction strategies. The given lack of community-based strategies in Chile was also emphasized by Sandoval and Voss and identified as a root cause of vulnerability [75]. The importance of financial resources was proved by a statistical analysis which Silva Bustos and Mena Amigo did for Chile [76]. The municipalities that show a moderate to low dependence on the common municipal fund have a low disaster risk, related to greater financial autonomy and own or self-management of resources, and the municipalities with lower percentages of poverty by income are better evaluated. This observation is fully in line with our own findings on the, compared with the rest of the countries, outstanding performance of the capital cities of Santiago de Chile and Quito-mainly due to the given financial resources and institutional capacities (see chapter 4). However, there is currently a new constitution in Chile under development, which may lead to a devolution of power and consequently aims to strengthen the governance of local administrators to reduce the risk disasters' factors and allow to mitigate conditions of existing vulnerability. This should go hand in hand with sufficient economic resources at the level of municipal governments, but also single households to benefit from their new upcoming constitutional rights.

Overall, there is still little participation and empowerment of citizens in the elaboration of communal civil protection plans in Chile [34]. The cadaster prepared by AMUCH (Región Metropolitana, Chile), even though it provides relevant information of municipal progresses, presents methodological inconsistencies: (1) it generates percentages from the sample that participated in the study and not from the total universe of municipalities; and (2) the methodology considers a self-declarative cadaster and not an empirical finding. In particular, there is lack of an adequate incorporation of multi-risks which is relevant as in the massive urbanization in eastern Santiago on the geologically active San Ramón fault [77].

Over the decades in Ecuador, the changes in the governance structure and the outcomes in the national and local DRR following the decentralization process, have made visible the reality of disparity between municipalities. In a country, where national equality in living standards, access to public services and the right to the city are among the main objectives of its constitutional mandate [78], the least prepared local governments face the challenge of complying and leading public affairs with limited institutional capacity and budget. Therefore, the success of the performance of local government assuming and managing DRR is increasingly seen as conditional on the specifics of each context. It is essential to acknowledge that two local governments have not the same politico-administrative approach, although being part of the same national territory [79].

Ecuador rewrote its National Constitution, which was approved by public referendum in September 2008. In this new Constitution, risk management is considered a State policy, proposing risk reduction measures through disaster mitigation, recovery and the improvement of social, economic and environmental conditions, to minimize vulnerability. Following this new criterion, the National Decentralized Risk Management System was created, establishing an institutional and regulatory framework to decentralize risk management and incorporate it in planning and development of instruments at all levels of government. Furthermore, Ecuador became the first country to recognize the Rights of Nature and the Right to the City in its basic law-a significant first step for humanity towards a change of paradigm. It includes the chapter: Rights for Nature, whose articles recognize that nature in all its forms of life has the right to exist, persist, maintain and regenerate its life cycles.

Again, after the 2016 earthquake, the institutional risk framework was strengthened. Specifically, the public health sector validated its disaster care protocols, preventing a number of local diseases' spread, but the national government and local government levels respond to different agendas and lack in coordination.

Interestingly, there is a regulatory framework linked to informal settlements, since the "Organic Law on Land-Use and Management" (LOOTUGS) recognizes in its § 74 "de facto settlements" as those characterized by a form of land occupation that has not been 
considered by planning, or that is in a risk zone [...] [80]. The LOOTUGS recognizes the role of the municipalities (GADMs) in their exercise of the "Organic Code of Territorial Organization, Autonomy and Decentralization" (COOTAD), in avoiding illegal invasions or settlements ( $\$ \mathrm{n} 458$ COOTAD). While risk management is defined by COOTAD as a competing competence for GADM, it does not have any funding allocation from the central to the local government. Local governments cannot follow up on the multiple top-down resolutions because of a lack of funding, staff and technical expertise.

Although the regulatory framework is well established, there is still an informal market of land. Beyond the evident urban poverty belts, there is strong weakness in controlling and/or steering the land market. Overall, the operability and implementation of the regulatory frameworks is still weak, specifically and mainly in mainstreaming inter-institutional cooperation schemes at different governmental levels and sectors.

Considering the nature of prioritization of development projects along the Guidelines for the inclusion of disaster risk management in the Development and Territorial Planning Plan (PDOT), none of the existing instruments inform a set of criteria which could aid prioritizing works and development projects that could reduce risk exposure.

Regarding the assessment of disaster risk, there are two specific shortcomings apart from the aforementioned lack of attention spent to multi-risk. First, the institutional perspective to "risk" is equal to "threat" and hinders integrated planning. Second, in the identification of risk areas and evacuation routes, there is a lack of active involvement and empowerment.

\section{Conclusions}

As outlined by the discussion section, both countries show considerable progresses in regard to the implementation of the UN-ISDR strategies, but we doubt that the existing global monitoring approach is appropriately designed for measuring the real situation in disaster risk assessment and management on the ground. The four output indicators target important objectives for disaster risk reduction, but there is, based on this study, no evidence that the chosen input indicators are adequately selected for explaining the observable pathways of the various countries towards the desired more sustainable development. For achieving sustainability, more participatory and inclusive approaches that aim at community-based strategies are required. In addition, multi-risk settings and cascading effects, caused by service disruptions of critical infrastructures need to be understood and addressed more adequately for resilience building.

The global monitoring is primarily designed as enforcement control (input indicators), combined with a control of target achievements (output indicators), but lacks a real control of the effectiveness of the existing disaster risk management, which cannot be done based on purely quantitative variables, but requires local knowledge gathered from document analysis, surveys and interviews. Our comparative study underlined the importance for more qualitative, in-depth studies on the root causes of disaster risk which could complement the global monitoring which is very much focused on quantitative data. This data basis is not sufficient for explaining the country's performance in regard to the global output targets.

Therefore, the set of indicators for the global input targets E and G should be complemented accordingly by key quality criteria of national as well as local disaster risk reduction strategies. These quality criteria should also be addressed by the national reporting requirements. Instead of providing just quantitative information, the countries should specifically address the four key priorities for action of the Sendai Framework. Currently, the common input targets of the Sendai Framework and the SDGs and consequently, the global monitoring, only partly address the key priorities of action of the Sendai Framework, which, for itself, surprisingly well describes the aforementioned weaknesses in Chile and Ecuador:

Priority 1 of the Sendai Framework targets the understanding of disaster risk: "Policies and practices for disaster risk management should be based on an understanding of disaster 
risk in all its dimensions of vulnerability, capacity, exposure of persons and assets, hazard characteristics and the environment" [1] (p. 14). Here, the need for a clear evidence basis is outlined which is widely missing in both countries regarding multi-risk settings and cascading effects. Priority 1 also reflects the global input target $\mathrm{G}$ on early warning.

Priority 2 aims at strengthening disaster risk governance to manage disaster risk: "Disaster risk governance at the national, regional and global levels. Clear vision, plans, competence, guidance and coordination within and across sectors, as well as participation of relevant stakeholders, are needed" [1] (p. 17). This priority enlightens the key role of land-use planning as a comprehensive, over-sectoral actor on the local level, which lacks sufficient resources in both countries.

Priority 3 tackles investments in disaster risk reduction for resilience: "Public and private investment in disaster risk prevention and reduction through structural and nonstructural measures" [1] (p. 18). Thus, economic resources are crucial-which is one of our key findings from both countries. Priority 4 is about enhancing disaster preparedness for effective response and to "Build Back Better" in recovery, rehabilitation and reconstruction phases, which is a critical opportunity for integrating disaster risk reduction into development measures, and thus, making nations and communities resilient to disasters. Again, it is land-use planning which is regarded as an important actor for Priority 4: "[ . . ] use opportunities during the recovery phase to develop capacities that reduce disaster risk in the short, medium and long-term, including through the development of measures such as land-use planning ( . . . )" [1] (p. 21). The widely unsolved problem of informal settlements in hazard prone areas was identified by this study as a common problem in both countries.

Author Contributions: Conceptualization, S.G.; methodology, S.G. and M.F.; writing-original draft preparation, S.G., L.S., K.-H.G., I.K.Q.M., B.P.L., M.M.J.G. and J.T.; writing-review and editing, S.G., L.S., K.-H.G., I.K.Q.M., B.P.L., M.M.J.G. and J.T.; supervision, S.G.; project administration, S.G.; funding acquisition, S.G. All authors have read and agreed to the published version of the manuscript.

Funding: The research presented in this article was part of the project "RIESGOS-Multi-risk analysis and information system components for the Andes region", funded by the German Federal Ministry of Education and Research as part of the funding measure "BMBF CLIENT I-International partnerships for sustainable innovations" of the framework program "Research for Sustainable Development (FONA3)", grant number: 03G0876 and the "Sustainable Intermediate Cities" Program implemented by the Deutsche Gesellschaft für Internationale Zusammenarbeit (GIZ) GmbH on behalf of the Ministry of Economic Cooperation and Development (BMZ) of the German Federal Government.

Institutional Review Board Statement: Not applicable.

Informed Consent Statement: Not applicable.

Data Availability Statement: The data presented in this study are available on request from the corresponding author.

Acknowledgments: We thank our colleagues from GIZ, GFA, IHS and Grupo Faro-Ecuador who provided insight and expertise that greatly assisted and sparked much of the research in Ecuador. We thank Karima Wanuz (GFA Consulting Group) and Alexander Jachnow (Institute for Housing and Urban Development Studies) for supporting the links and ties between the Institute for Spatial Planning (IRPUD) of the TU Dortmund University and the Geological and Energy Research Institute (IIGE) towards a holistic approach and the use of innovative methods for multi-risk assessment and management in intermediate cities in Ecuador. We thank the GIZ Program "Sustainable Intermediate Cities" (CIS), particularly César Valencia (GIZ) and José Morales (GIZ) who together with Julio López and Cristhian Parrado (Grupo Faro-Ecuador) generated the necessary spaces of exchange with the local and provincial governments in Latacunga and Cotopaxi as well as supported all possible synergies with the RIESGOS Project and its partners. From the Chilean side, we want to thank Natalia Andrea Silva Bustos (ONEMI), who contributed from the institutional perspective regarding the implementation of the Sendai Framework in Chile.

Conflicts of Interest: The authors declare no conflict of interest. 


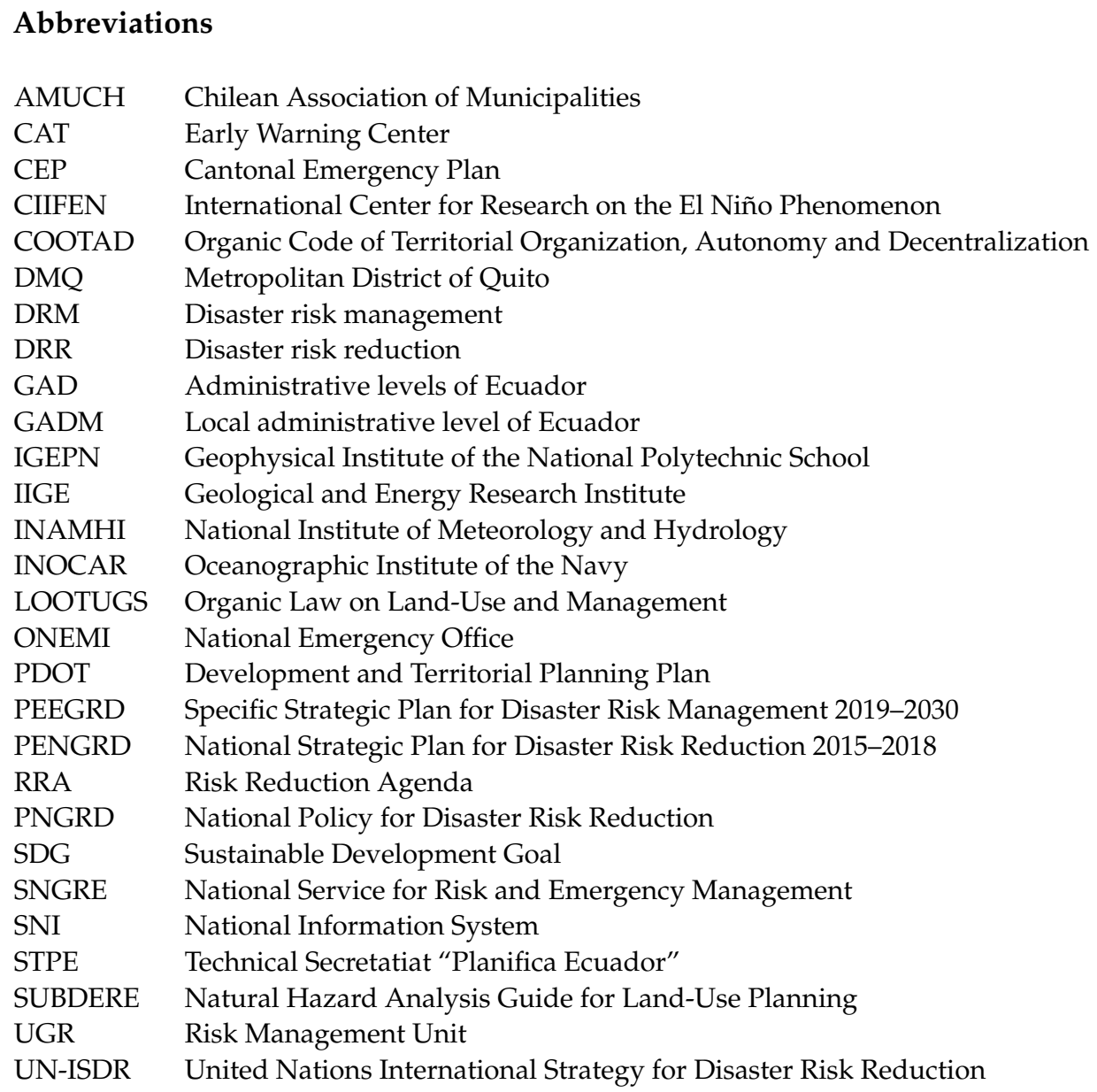

\section{References}

1. UN-ISDR. Sendai Framework for Disaster Risk Reduction 2015-2030. Geneva. Available online: https://www.preventionweb. net/files/43291_sendaiframeworkfordrren.pdf (accessed on 4 April 2018).

2. UN. Take Action for the Sustainable Development Goals. Common indicators. Available online: https://www.un.org/ sustainabledevelopment/sustainable-development-goals/ (accessed on 2 November 2020).

3. UN-ISDR. Sendai Framework Indicators. Available online: https://www.preventionweb.net/sendai-framework/sendaiframework-monitor/indicators (accessed on 2 November 2020).

4. UN-ISDR. Integrated monitoring of the global targets of the Sendai Framework and the Sustainable Development Goals. Available online: https: / www.preventionweb.net/sendai-framework/sendai-framework-monitor//common-indicators (accessed on 2 November 2020).

5. UN-ISDR. Global Assessment Report 2019. Available online: https://gar.undrr.org/sites/default/files/reports/2019-05/full_ gar_report.pdf (accessed on 2 November 2020).

6. ANALYTICS. Available online: https://sendaimonitor.undrr.org/analytics/global-targets/13 (accessed on 2 November 2020).

7. DECLARACIÓN PAÍS CHILE VI PLATAFORMA GLOBAL PARA LA REDUCCIÓN DEL RIESGO DE DESASTRES. Available online: https:/ / www.preventionweb.net/files/globalplatform/Declaracion\%20Chilena_PG19\%20Rev\%200NEMI\%20-\%20 MINREL.docx (accessed on 2 November 2020).

8. Cutter, S.L. Vulnerability to environmental hazards. Prog. Hum. Geogr. 1996, 20, 529-539. [CrossRef]

9. Burby, R.J. Cooperating with Nature: Confronting Natural Hazards with Land-Use Planning for Sustainable Communities; Joseph Henry Press: Washington, DC, USA, 1998; 376p.

10. Godschalk, D.R.; Beatley, T.; Berke, P.; Brower, D.J.; Kaiser, E.J. Natural Hazard Mitigation: Recasting Disaster Policy and Planning; Island Press: Washington, DC, USA, 1999.

11. Sapountzaki, K.; Wanczura, S.; Casertano, G.; Greiving, S.; Xanthopoulos, G.; Ferrara, F. Disconnected policies and actors and the missing role of spatial planning throughout the risk management cycle. Nat. Hazards 2011, 59, 1445-1474. [CrossRef]

12. Greiving, S.; Tesliar, J.; Ubaura, M. (Eds.) Spatial Planning and Resilience Following Disasters-International and Comparative Perspectives; Policy Press: Bristol, UK, 2016; 354p.

13. Gallina, V.; Torresan, S.; Critto, A.; Sperotto, A.; Glade, T.; Marcomini, A. A review of multi-risk methodologies for natural hazards: Consequences and challenges for a climate change impact assessment. J. Environ. Manag. 2016, 168, 123-132. [CrossRef] 
14. Schmidt, J.; Matcham, I.; Reese, S.; King, A.; Bell, R.; Henderson, R.; Smart, G.; Cousins, J.; Smith, W.; Heron, D. Quantitative multi-risk analysis for natural hazards: A framework for multi-risk modelling. Nat. Hazards 2011, 58, 1169-1192. [CrossRef]

15. European Commission. Risk Assessment and Mapping Guidelines for Disaster Management; European Commission: Brussels, Belgium, 2010; SEC(2010) 1626 final.

16. Poljanšek, K.; Marín Ferrer, M.; De Groeve, T.; Clark, I. (Eds.) Science for Disaster Risk Management 2017: Knowing Better and Losing Less; EUR 28034 EN; Publications Office of the European Union: Luxembourg, 2017; JRC102482; ISBN 978-92-79-60679-3. [CrossRef]

17. Scolobig, A.; Garcia-Aristizabal, A.; Komendantova, N.; Patt, A.; Di Ruocco, A.; Gasparini, P.; Monfort, D.; Vinchon, C.; Bengoubou-Valerius, M.; Mrzyglocki, R.; et al. From Multi-Risk Assessment to Multi-Risk Governance: Recommendations for Future Directions. In Chapters 3-20: International Bank for Reconstruction and Development "Understanding Risk: The Evolution of Disaster Risk Assessment"; International Bank for Reconstruction and Development: Washington, DC, USA, 2014 ; pp. $163-167$.

18. Pelling, M. Adaptation to Climate Change: From Resilience to Transformation; Routledge: London, UK, 2011 ; ISBN 9780415477512.

19. Biggs, R.; Schlüter, M.; Schoon, M.L. Principles for Building Resilience: Sustaining Ecosystem Services in Social-Ecological Systems; Cambridge University Press: Cambridge, UK, 2015; ISBN 978-1-107-08265-6.

20. Adger, W.N.; Hughes, T.P.; Folke, C.; Carpenter, S.R.; Rockström, J. Social-ecological resilience to coastal disasters. Science 2005, 309, 1036-1039. [CrossRef] [PubMed]

21. Agyeman, J. Environmental justice and sustainability. In Handbook of Sustainable Development; Atkinson, G., Dietz, S., Neumayer, E., Agarwala, M., Eds.; Edward Elgar Publishing: Cheltenham, UK, 2014; pp. 188-205.

22. Sarabia, M.M.; Kägi, A.; Davison, A.C.; Banwell, N.; Montes, C.; Aebischer, C.; Hostettler, S. The challenges of impact evaluation: Attempting to measure the effectiveness of community-based disaster risk management. Int. J. Disaster Risk Reduct. $2020,49$. [CrossRef]

23. Center for Excellence in Disaster Risk Management \& Humanitarian Assistance. Chile Disaster Management Reference Handbook 2017. Available online: https:/ / reliefweb.int/report/chile/chile-disaster-management-reference-handbook-may-2017 (accessed on 22 November 2020).

24. World Bank; UNPD. The World Bank Data. Retrieved from Urban Population (\% of Total)—Chile. Available online: https: / / datos.bancomundial.org/indicador/SP.URB.TOTL.IN.ZS?locations=CL (accessed on 2 November 2020).

25. Jiménez-Cavieres, F. Chilean Housing Policy: A Case of Social and Spatial Exclusion; LIT: Berlin, Germany, 2006.

26. UNDP. Desiguales. Orígenes, Cambios y Desafíos de la Brecha Social en Chile; United Nations Development Program: Santiago, Chile, 2017.

27. UN. Diagnóstico de la Situación de la Reducción del Riesgo de Desastres en Chile; United Nations: Santiago, Chile, 2010.

28. ONEMI. Plan Estratégico Nacional para la Gestion de Riesgo de Desastres 2015-2018; Chilean Ministry of the Interior and Public Security: Santiago, Chile, 2016.

29. Camus, P.; Arenas, F.; Lagos, M.; Romero, A. Visión histórica de la respuesta a las amenazas naturales en Chile y oportunidades de gestión del riesgo de desastre. Rev. Geogr. Norte Gd. 2016, 64, 9-20. [CrossRef]

30. Metropolitan Regional Government. Regional Disaster Risk Reduction Plan; Metropolitan Regional Government: Santiago, Chile, 2018.

31. Valparaiso Regional Government. Disaster Risk Reduction Plan; Valparaiso Regional Government: Valparaíso, Chile, 2018.

32. TECHO. Informe Final. Actualización del Catastro Nacional de Campamentos. Centro de Investigación Social; TECHO: Santiago, Chile, 2018.

33. GUÍA ANÁLISIS DE RIESGOS NATURALES PARA EL ORDENAMIENTO TERRITORIAL. Available online: http:// www.subdere.gov.cl/sites/default/files/documentos/libro_guia_de_analisis_de_riesgos_naturales_para_el_ordenamiento_ territorial_.pdf (accessed on 3 November 2020).

34. Sánchez, R. La debilidad de la gestión del riesgo en los centros urbanos. El caso del Área Metropolitana de Santiago de Chile. Rev. Geogr. Norte Gd. 2010, 47, 5-26. [CrossRef]

35. World Bank. Disaster Risk Management in Latin America and the Caribbean Region: GFDRR Country Notes Ecuador. Available online: https:/ / www.gfdrr.org/sites/default/files/publication/drm-country-note-2010-ecuador.pdf (accessed on 22 November 2020).

36. SGR (Secretaría de Gestión de Riesgos). Ecuador: Referencias Básicas para la Gestión de Riesgos 2013-2014; Secretaría de Gestión de Riesgos: Quito, Ecuador, 2012.

37. Municipio del Distrito Metropolitano de Quito. Plan Metropolitano de Desarrollo y Ordenamiento Territorial 2015-2025; Municipio del Distrito Metropolitano de Quito: Quito, Ecuador, 2015.

38. Subsecretaría de Hábitat y Asentamientos Humanos. Informe Nacional del Ecuador para la Tercera Conferencia de las Naciones Unidas sobre la Vivienda y de Desarrollo Urbano Sostenible HABITAT III; Ministerio de Desarrollo Urbano y Vivienda del Gobierno de la República del Ecuador: Quito, Ecuador, 2015.

39. Instituto Geográfico Militar IGM. Mapa Físico; IGM: Quito, Ecuador, 1999.

40. Tomorrow's Cities-Urban Risk in Transition. Geoportal of the Quito Urban Information Centre Launched. Available online: https:/ / www.tomorrowscities.org/geoportal-quito-urban-information-centre-launched (accessed on 2 November 2020).

41. Municipality of Quito. Atlas Amenazas Naturales DMQ. Available online: https://archive.org/details/AtlasAmenazasNaturalesDMQ/ page/n15/mode/2up (accessed on 8 November 2020). 
42. Tomorrow's Cities—Urban Risk in Transition: Quito del Mañana (Tomorrow's Quito). Available online: https://tomorrowscities. org/city / quito (accessed on 2 November 2020).

43. Quito celebrates the launch of the Metropolitan Disaster Risk Reduction Management Plan. Available online: https: / / eird.org/americas/news / quito-celebrates-the-launch-of-the-metropolitan-disaster-risk-reduction-management-plan.html\# .X9MoD7MxmUl (accessed on 11 December 2020).

44. Repositorio Digital. Oficina Nacional de Emergencias del Ministerio de Seguridad Pública de Chile. Available online: http: / / repositoriodigitalonemi.cl/handle/123456789/3363 (accessed on 6 December 2020).

45. ONEMI. Política Nacional para la Gestión de Riesgo de Desastres. Available online: https://repositoriodigitalonemi.cl/web/ bitstream/handle/2012/1710/POLITICA_NAC_2016_ESP.pdf (accessed on 11 December 2020).

46. Quintana Mi ralles, I.K.; Larraín, B.P. Information Derived from Interview with Representative of ONEMI on 16 January 2021, Santiago, Chile, Interview. 2021.

47. Servicio Nacional de Gestión de Riesgos y Emergencias. Ecuador consolida el Acuerdo Nacional para la Reducción de Riesgo de Desastres 2030. Available online: https:/ / www.gestionderiesgos.gob.ec/ecuador-consolida-el-acuerdo-nacional-para-lareduccion-de-riesgo-de-desastres-2030/ (accessed on 11 December 2020).

48. Servicio Nacional de Gestión de Riesgos y Emergencias. Plan Específicode Gestión de Riesgos. Available online: https: //www.defensa.gob.ec/wp-content/uploads/downloads/2019/07/plan-nacional-riesgos-web.pdf (accessed on 11 December 2020).

49. AMUCH. Catastro de Capacidades Municipales para la Gestión de Riesgos de Desastres y Emergencias; Dirección de Estudios, Asociación Chilena de Municipalidades: Santiago, Chile, 2019.

50. ONEMI. Plan Estratégico Nacional para la GRD 2015-2018. Available online: https://siac.onemi.gov.cl/documentos/PLAN_ ESTRATEGICO_BAJA.pdf (accessed on 11 December 2020).

51. ONEMI. Retrieved from Centro de Alerta Temprana. Available online: https://www.onemi.gov.cl/cat/https://www.onemi.gov. $\mathrm{cl} / \mathrm{cat} /$ (accessed on 14 November 2020).

52. SAE-Gobierno de Chile. Retrieved from Sistema de Alerta de Emergencias. Available online: http://www.sae.gob.cl/http: / / www.sae.gob.cl/ (accessed on 14 November 2020).

53. ONEMI. Obtenido de Noticias ONEMI. Available online: https://www.onemi.gov.cl/noticia/el-68-de-los-municipios-lolargo-de-chile-ha-informado-onemi-que-cuenta-con-un-plan-comunal-de-emergenciahttps://www.onemi.gov.cl/noticia/el68-de-los-municipios-lo-largo-de-chile-ha-informado-onemi-que-cuenta-con-un-plan-comunal-de-emergencia (accessed on 14 November 2020).

54. Sada, K.-H.G. Personal Communication, Expert interview with representative of the Asociación de Profesionales de Ries-go-on 6 November 2020.

55. ONEMI, Oficina Nacional de Emergencia del Ministerio del Interior y Seguridad Pública. Retrieved from Regiones. Available online: https:/ / www.onemi.gov.cl/region/ (accessed on 14 November 2020).

56. UNESCO. Análisis de Riesgo de Desastres en Chile. VII Plan de Acción DIPECHO en Sudamerica 2011-2012; United Nations Educational, Scientific and Cultural Organization: Santiago, Chile, 2011.

57. Ecuadorlistoysolidario. Available online: https://www.ecuadorlistoysolidario.gob.ec/ (accessed on 14 November 2020).

58. ONEMI, Oficina Nacional de Emergencia del Ministerio del Interior y Seguridad Pública. Retrieved from Chile Preparado. Available online: https:/ / www.onemi.gov.cl/visor-chile-preparado/ONEMI (accessed on 14 November 2020).

59. ONEMI, Oficina Nacional de Emergencia del Ministerio del Interior y Seguridad Pública. Available online: https://www.onemi. gov.cl/mapas / (accessed on 14 November 2020).

60. Valdivieso, P.; Andersson, K.P. Local Politics of Environmental Disaster Risk Management: Institutional Analysis and Lessons from Chile. J. Environ. Dev. 2017, 26, 51-81. [CrossRef]

61. Weichselgartner, J.; Kasperson, R. Barriers in the science-policy-practice interface: Toward a knowledge-action-system in global environmental change research. Glob. Environ. Chang. 2009, 20, 266-277. [CrossRef]

62. Renn, O. Risk Governance. Coping with Uncertainty in a Complex World; Earthscan: London, UK, 2008 ; ISBN 9781844072927.

63. Fleischhauer, M.; Greiving, S.; Flex, F.; Scheibel, M.; Stickler, T.; Sereinig, N.; Koboltschnig, G.; Malvati, P.; Vitale, V.; Grifoni, P.; et al. Improving the active involvement of stakeholders and the public in flood risk management-Tools of an involvement strategy and case study results from Austria, Germany and Italy. Nat. Hazards Earth Syst. Sci. 2012, 12, 2785-2798. [CrossRef]

64. Greiving, S.; Du, J.; Puntub, W. Managed Retreat-A Strategy for the Mitigation of Disaster Risks with International and Comparative Perspectives. J. Extrem. Events 2018, 5, 1850011. [CrossRef]

65. Sandoval, V.; Sarmiento, J.P. A neglected issue: Informal settlements, urban development, and disaster risk reduction in Latin America and the Caribbean. Contributing Paper to GAR 2019. Available online: https://www.undrr.org/publication/neglectedissue-informal-settlements-urban-development-and-disaster-risk-reduction (accessed on 27 December 2020).

66. Rosero Velásquez, H.; Straub, D. Representative Natural Hazard Scenarios for Risk Assessment of Spatially Distributed Infrastructure Systems in Santiago de Chile. In Proceedings of the 29th European Safety and Reliability Conference (ESREL 2019), Hannover, Germany, 22-26 September 2019.

67. Dueñas-Osorio, L.; Kwasinski, A. Quantification of Lifeline System Interdependencies after the 27 February 2010 Mw 8.8 Offshore Maule, Chile, Earthquake. Earthq. Spektra 2012, 28, 581-603. 
68. Pichinchacomunicaciones. Available online: http://www.pichinchacomunicaciones.com.ec/secretaria-de-gestion-de-riesgosdecreto-alerta-roja-por-erosion-del-rio-coca/ (accessed on 4 December 2020).

69. Global Facility for Disaster Reduction and Recovery (GFDRR). Climate Risk and Adaptation Country Profile: Ecuador. Vulnerability, Risk Reduction, and Adaptation to Climate Change. Available online: https://www.gfdrr.org/en/publication/climaterisk-and-adaptation-country-profile-ecuador (accessed on 22 November 2020).

70. World Bank. Climate Change Knowledge Portal. Country Chile. Available online: https:/ climateknowledgeportal.worldbank. org/country/chile/vulnerability (accessed on 22 November 2020).

71. Field, C.B.; Barros, T.F.; Stocker, Q.D.; Dokken, D.J.; Ebi, K.L.; Mastrandrea, M.D.; Mach, K.J.; Plattner, G.-K.; Allen, S.K.; Tignor, M.; et al. Managing the Risks of Extreme Events and Disasters to Advance Climate Change Adaptation; A Special Report of Working Groups I and II of the Intergovernmental Panel on Climate Change; Cambridge University Press: Cambridge, UK, 2012.

72. van Ruijven, B.J.; Levy, M.A.; Agrawal, A.; Biermann, F.; Birkmann, J.; Carter, T.R. Enhancing the relevance of Shared Socioeconomic Pathways for climate change impacts, adaptation and vulnerability research. Clim. Chang. 2014, 122, 481-494. [CrossRef]

73. Greiving, S. Disaster response and spatial planning-Key challenges and strategies. In Spatial Planning and Resilience Following Disasters - International and Comparative Perspectives; Greiving, S., Tesliar, J., Ubaura, M., Eds.; Policy Press: Bristol, UK, 2016; pp. 1-15.

74. UNDP. Diagnóstico de Necesidades de Capacitación para la Formación en Chile de la Reduccion del Riesgo de Desastres; United Nations Development Program: Santiago, Chile, 2014.

75. Sandoval, V.; Voss, M. Disaster Governance and Vulnerability: The Case of Chile. Politics Gov. 2016, 4, 107-116. [CrossRef]

76. Silva Bustos, N.; Mena Amigo, C. Identifying the Underlying Risk Factors of Local Communities in Chile, United Nations Office for Disaster Risk Reduction, Contributing Paper to GAR 2019. Available online: https://www.undrr.org/publication/identifyingunderlying-risk-factors-local-communities-chile (accessed on 22 November 2020).

77. Easton, G.; Inzulza Contardo, J.; Pérez Tello, S.; Ejsmentewicz Cáceres, D.; Jiménez Yáñez, C. ¿Urbanización fallada? La Falla San Ramón como nuevo escenario de riesgo sísmico y la sostenibilidad de Santiago, Chile. Rev. Urban. 2018, 38, 1-20. [CrossRef]

78. Government of Ecuador. Constitución de la República del Ecuador. Available online: http://www.corteconstitucional.gob.ec/ images/stories/pdfs/Constitucion_politica.pdf (accessed on 22 November 2020).

79. Heinrichs, D. How Decentralization and Governance shape local planning practice. Rhetoric, reality and the lessons from the Philippines. Spring Res. Ser. 2006, 46, 12-24.

80. Gobierno de la República del Ecuador. Ley Orgánica de Ordenamiento Territorial, Uso y Gestión del Suelo; (LOOTUGS), 5 July 2016, Registro Oficial No 790; Gobierno de la República del Ecuador: Quito, Ecuador, 2016. 